\section{SCIENCE MASTERS' ASSOCIATION ANNUAL MEETING}

$\mathrm{T}_{\text {of }}^{\mathrm{T}}$ 'HE annual meeting of the Science Masters' Association was held in the Science Department of the City of London School during April 9-11.

The presidential address by Mr. C. L. Bryant, late of Harrow School, and now, in his own words, of Perranporth Youth Club, dealt with "The Impact of Science on Human Beliefs". The theme was worthy of one who, for nearly forty years, has served the Association faithfully and well. Christian missions are criticized because they uproot the faith of the natives without planting anything more suitable in its place. Science is doing that here and now. Until about fifty years ago, men believed, more or less, what the Churches told them. Now, for the most part they believe in nothing at all; not even in science, except as a provider of luxuries. This is largely because there is no background of philosophy to the science which is commonly taught in schools. Many of the Churches are hampered by creeds in which minor and debatable points are magnified into articles of belief. It is difficult for a scientific layman to discuss such matters with ecclesiastics. In the interests of truth the barriers should be broken down, and Mr. Bryant pleaded for an approach between science and religion for (as we have recently seen) "where there is no vision the people perish". A group of members under Mr. Bryant's leadership is to tackle the problem.

"The Social Relations of Science" was the title of the Science and Citizenship Lecture given by Mr. J. G. Crowther, of the British Council. Mr. Crowther traced the development of scientific research from the small-scale activity before the War of 1914-18 to its present highly organized state, and outlined the consequent revolutionary changes in the place of science in the life of mankind in the last twenty years, and foreshadowed the equally great developments to be made in the next twenty years. Where are the men of science to come from to stimulate the application of science to many aspects of life in Britain? That is an educational problem. One of our chief tasks is to use the ability and enthusiasm of men of moderate ability much more efficiently than at present. In the education of such men the science master should be given every encouragement and material assistance, and such education should include a thorough study of the relation of science to other human activities. The men we need should be "statesmen of science" who approach the problems of humanity with the knowledge and understanding of statesmen; statesmen who approach them with a knowledge and understanding of science.

A large audience was privileged to hear Sir Alexander Fleming describe his discovery of penicillin and the subsequent researches which led to its manufacture and chemical use. By means of an excellent series of lantern slides he led his audience through years of patient researches with a clarity of exposition that enabled each to feel the thrill of discovery. He described the work of the chemists in isolating the pure substance and the skill with which they overcame the major obstacle of its instability. No written account could do justice to a lecture which combined lucidity with dry humour and conversational intimacy.

Mr. J. McG. Bruckshaw, of Imperial College, spoke on "Physics and Economic Geology" and gave a clear outline of the application of physics to the problem of locating mineral deposits. Mr. F. W. Cuckow, of the National Physics Laboratory, gave a fascinating account of the development and scope of the electron microscope; members enjoyed the speeker's intimate style and an excellent series of lantern slides. Mr. R. Maitland dealt with the chemistry of plastics, including an account of the replacement of carbon by silicon in the giant molecule. Mr. C. Bibby, education officer, Central Council for Health Education, talked eloquently on health education through school biology. The importance was stressed of distinguishing between habits which were the disciplining of natural functions and those aesthetic habits which were really habits of civilization.

A film show and discussion was held in the Ministry of Information theatre. Mr. Arthur Elton, president of the Scientific Film Association, opened by speaking on the scope and limitations of the science teaching film. Scientific films of a suitable nature were few, and he thought that it was the duty of the teaching profession to lay down their policy for films in collaboration with the Scientific Film Associationthe kind of films they wanted and for what agegroups. Science films, including the "Transfer of Power" which was produced and directed by Arthur Elton and Geoffrey Bell, were shown. Mr. Geoffrey Bell discussed the film critically in a short talk on the making of a film. He stressed the need for careful research and script, good production and skilful editing; and invited the co-operation of members in helping to make good films. Mr. W. Farr, head of the Central Film Library of the Ministry of Information, spoke on the distribution of films. He hoped to see a Central Film Library linked with a number of local libraries-possibly twelve regional libraries dealing with free distribution of educational films to schools. Many members took part in the subsequent discussion. It was agreed that the best equipment for a school was one sound projector for use in the main hall plus one or more smaller silent machines for classroom use. A plea was made for using teachers not only in suggesting titles and the contents of scripts but also in the production of films and in getting better commentaries. The various types of films needed-historical, revision, etc.-were discussed and the relative advantages of film and film strip assessed. Members were pleased to learn that the Education Section of the Scientific Film Association were en. gaged in preparing lists of suitable films and of the offer of Imperial Chemical Industries, Ltd., to produce scientific films for purely educational purposes.

A general discussion on the role of science in the future educational system was opened by Mr. A. W. Wellings (Leamington College) and Mr. D. H. J. Marchant (Ilford County School). Mr. Wellings, after examining the criticism of existing science teaching, stressed the great opportunities for the Association to seo that, within the general educational framework provided under the new Act, science teaching plays a vital part in preparing pupils for the difficult and exciting job of living in a rapidly changing world. He pleaded for emphasis on the adventure of science, and for an alteration in technique, and a new attitude, so that the pupils get a better idea of the way in which science affects human activities and progress at every point, and can be led to realize that the problems created by science will be, in part, theirs to solve. He gave suggestions how this could be attempted, including a ploa for a re-orientation of chemical studies, so that they could 
be taught from the point of view of natural resources. Mr. Marchant dealt with the content of science courses. He advocated general science for all types of school, but emphasized that, although the course should cover a fairly wide field, whatever is taught must be science. He offered valuable suggestions on the elimination of irrelevant matter and on the economy of time and effort by presenting subjects with due consideration of the stage best suited to the difficulties. In developing theories, the tempo should not be that of research workers but accelerated in proportion to the richer background of fact which may now be assumed. Syllabuses should be planned concentrically so that general science and its possibilities for good could be worked out. Many members made valuable contributions to the discussion. Practical points such as the time allocation for science teaching (where the subject is taken to two credit stage in the School Certificate the allowance should be the same as for two separate science subjects), laboratory equipment, the relation between preschool certificate work and post-school certificate studies, and courses for teachers. A plea was made for a fundamental approach so that science can be seen in proper perspective in the whole education of the future man. It was interesting to note, as distinct from pre-war discussions, that members seemed to assume that it was general science, and not separate science subjects, to be discussed.

The Members' Exhibition, though smaller than in recent years, was up to its usual high standard; and visits were made to hospitals, newspaper offices, the General Post Office and other places of scientific interest.

\section{MARINE AND OTHER BIOLOGICAL LABORATORIES}

\author{
By Prof. J. H. ORTON \\ University of Liverpool
}

$\mathrm{D}$ URING the war years, there have been a number of communications in Nature ${ }^{1-4}$ on marine biological laboratories. It is possible that a review of these may be useful at the present time.

\section{Great Britain}

For many decades the Marine Biological Laboratory at Plymouth has been the centre of fundamental marine biological research in Great Britain; it has been the Mecca of zoologists from most British and many foreign universities. The chief reasons for the success of Plymouth are as follows. First, the abundance and variety of the fauna, the constituents and biology of which have steadily been defined by a succession of naturalists. The Laboratory was also able to supply research material at all times. The accessibility of Plymouth from the situation of the older universities was also important. The policy of the director, which pervaded the staff, has always been to hold to the principle that visiting and other researchers must be supplied with whatever living or other material they needed for their researches, so far as it was in the power of the staff and station to supply it. The policy of the Council has been to attract the nascent generation of zoologists as students of courses in marine biology, including ship and shore expeditions, and so to display the attractions of the subject and the station, and bring together researchers working on a variety of problems. Lastly, sustained and increasing support was given by governmental departments, and especially the Development Commission, to the Laboratory.

Thus, a visiting researcher knew from the published fauna list ${ }^{5}$ what animals-or plants-he could expect to get in a living condition, and also that he would be given every reasonable help to conduct his researches. In the circumstances, a great variety of workers was attracted to the station, and their publications $^{6}$ show that investigations have been made over the whole range of biology, namely, morphology, systematics, embryology, growth, lifehistory, food and mode of feeding, digestion, general physiology, sex and breeding, variation and heredity, ecology, behaviour and mortality, as well as the more limited and special problems of marine biology.

With this perspective in mind, it is easy to understand the growing need of the newer universitiesless conveniently situated to Plymouth than the older-for a laboratory in proximity to them where facilities for study comparable to those at Plymouth can be attained.

Marine biological laboratories have also been established at Port Erin (University of Liverpool), Millport (University of Glasgow), Cullercoats (University of Durham), St. Andrews, Nigg (University of Aberdeen), Robin Hood's Bay (University of Leeds), the Government stations at Lowestoft and Conway, Lough Ine (University College, Cork) in Eire, while the Welsh universities are also requiring one at Bangor. There is undoubtedly scope of some kind for all these stations, if scope be defined as facilities for visiting researchers, for special marine biological researchers and provision for student vacation courses. All these laboratories, except Lowestoft and Conway, differ from that at Plymouth in belonging to universities, and as such had to compete in pre-war years with other departments for the limited funds available, or be dependent upon external sources for existence; but as the external source was mainly the Development Commission (Advisory Committee on Fishery Research), which quite correctly gave its major support to the definitive research station at Plymouth, there was little financial support left for the university marine laboratories.

The question now arises what functions these labboratories are to serve in post-war years. In a long-term policy, are the prospects in marine biological research such as to justify the staffing of all these laboratories with research workers? If the staffs were provided, would they find an adequate outlet for their energies and careers, and also supply in a succession of personnel the needs for fishery and other research posts (including economic and in. dustrial requirements) of Britain and the British Empire? The answers to these questions of policy are not simple. If we look no further ahead than twenty years, probably the answers can all be given in the affirmative. There is, however, need for caution in their own interest against over-production of marine biologists in the post-war years.

There is no doubt that all the university marine stations can pay handsome dividends for facilities for research in general biology, and for that familiarization of senior and junior students with the problems of living marine animals and plants and their habitats which constitutes for most students the most attractive part of a biology course. To this end it is necessary to maintain at least skeleton staffs in all stations.

Thus the claims of the different university stations 